\title{
Viability of Musharakah as an Alternative Financing Mode for Small and Medium Enterprises: The Cases of Klang Valley and Selangor, Malaysia
}

\author{
Dzuljastri Abdul Razak, ${ }^{1}$ Mustafa Omar Mohammed, ${ }^{2}$ Nur Hasnida Abd Rahman, ${ }^{3}$ \\ ${ }^{1,2}$ Kuliyyah of Economics and Management Sciences, International Islamic University Malaysia, \\ ${ }^{3}$ Institute of Islamic Banking and Finance (IIiBF), International Islamic University Malaysia
}

\begin{abstract}
Small and Medium Enterprises ("SMEs") have been recognized as one of the most important component that contributes towards the economic growth of many countries around the world. Despite its importance, SMEs have limited access to external financing that is dominated by debt financing. They have difficulty in fulfilling debt requirements particularly in providing collateral, coping with high interest/ profit payment and adapting to credit rationing. Such limitations curb their growth and expansion. Therefore, there is a need to explore an alternative financing, which is more accessible by SMEs. This study examines the viability of Musharakah as an alternative financing mode for SMEs.

Quantitative method is adopted in this study. Questionnaires were self-administered, using drop-off method, to a sample of 100 SMEs firms in Klang Valley and Selangor, Malaysia. The data were analyzed using Exploratory Factor Analysis. Musharakah is found to be a viable alternative financing mode for SMEs. Its three main features, namely (i) risks sharing (ii) profit and loss sharing and (iii) participation have immense potential of salvaging SMEs from their debt based challenges of access to financing: collateral, high interest rate and credit rationing. The study area is limited to the samples in Klang Valley and Selangor, Malaysia.

This study contributes towards a better understanding of the potential of Musharakah as a viable financing for SMEs. Hence, it provides foundation and direction in structuring Musharakah as an alternative financing mode for SMEs.
\end{abstract}

Keywords: SMEs, Debt Financing, Justice, Musharakah and Factor Analysis

\section{Introduction}

Small and Medium Enterprises (SMEs) represent more than $90 \%$ of the total business establishment for most of the countries around the world. They contribute to the economic growth of the countries, employment, domestic import substitution and poverty alleviation. For example, SMEs' contribution to GDP is $60 \%$ (China), $57.0 \%$ (Germany), $55.3 \%$ (Japan), 56\% (Indonesia) and 46\% (Singapore). SMEs' contribution to employment is 90\% (Indonesia), 82\% (China), 78\% (Thailand), 70\% (Japan and Singapore) and 61.3\% (Germany). Despite its importance, past literatures has discussed that SMEs have difficulty in getting access to external financing which in turn, prevent their growth and development (Shinozaki, 2012; Rasiah, 2011; Oum, Harvie\&Narjoko, 2010; Salleh\&Ndubisi, 2006; Thorsten \&Demirguc, 2006; and Berger and Udell, 1998). This is because the main source of external financing for SMEs which is the banking institution operates mainly on debt based system which is not easily accessible by SMEs. This is due to their inability to fulfill debt requirement mainly in providing collateral, sufficient track records, ability to pay high interest expenses, credit rationing, etc. (ShamsubaridahRamlee and Berma, 2013; Rasiah, 2011; MohaAsri and Khadijah, 2011; NormahAris, 2007; Salleh and Ndubisi, 2006; Thorsten and Demirguc, 2006; Berger and Udell, 1998).

As financing is crucial to facilitate SMEs' growth and development, SMEs would require an alternative financing which is easily accessible by them. SMEs which operate in a small to medium scale usually have no assets to be pledged as collateral and have no capacity to oblige high interest payment. However, they might have great ideas and skills which can be transformed into a viable business. Therefore, as pointed by Berger \&Udell (2002) evaluation for small lending should emphasize on the soft information such as character of the

Corresponding Author: Dzuljastri Abdul Razak, email: dzuljastri@iium.edu.my 
entrepreneurs and reliability of the firm's owner rather than hard information such as financial ratios and collateral values. Thus, SMEs would require an alternative financing which consider viability of the business instead of highly relying on collateral and ability to pay high interest payment. Apparently, many scholars such as Chapra (1992), Siddiqui (2006), Usmani (1998) and Al Harran (1993) in their writings have highlighted that these features are available under Islamic equity based financing namely Musharakah financing.

Even though there are few past studies which suggest Musharakah as an alternative financing for SMEs (VeelaipornPromwichit, ShamsherMohamad and Taufiq Hassan, 2013; FaraMadeha, 2007; Chapra, 1992 and Al Harran, 1990) to the best knowledge of the researcher, there is no comprehensive study done so far to explore Musharakah financing for SMEs particularly in Malaysia. Therefore, this study is conducted to examine the viability of Musharakah as a viable financing for SMEs. This study is divided into six sections. Section 1 gives introduction of the study, followed by review of literature in section 2. Research methodology is discussed in section 3 and the results are presented in section 4 . Section 5 provides discussion on the findings and finally, section 6 concludes the study.

\section{Literature Review}

As explained in section 1, most SMEs face difficulty in getting access to financing due to their inability to fulfill debt financing requirement and therefore, alternative financing need to be sought. In response to this problem, this study intends to examine viability of Musharakah financing as an alternative financing for SMEs. This section discusses what are the issues faced by SMEs in the current debt financing system in subsection 2.1. Subsequently, subsection 2.2 elaborates the potential of Musharakah financing for SMEs.

\subsection{Issues in Debt Financing}

Past literature discussed that most SMEs face difficulty in getting access to external financing, particularly from the banking institutions. This is because most of the financing products offered by the banks are in a form of debt which is not easily accessible by SMEs due to their inability to fulfill debt requirements such as collateral, track record, high interest payment and credit rationing (HasnahHaron, Saniza Said, Jayaraman \& Ishak Ismail; 2013, Shamsu baridah Ramlee \& Berma; 2013, Rasiah; 2011, Normah Aris; 2007 and Beck \& Demirguc; 2006). There are also studies which discuss SMEs' difficulties in getting access to financing is due to the problem of information asymmetry (Berger \&Udell, 1998). Information asymmetry arises due to one party having better information than another party (Akerlof, 1970). Information asymmetry results in two problems namely adverse selection and moral hazard. In the context of banking relationship, adverse selection is a problem where the banks are exposed to the risks of financing companies that are not suitable for lending when the bank face difficulty to select and distinguish healthy borrowers from those that are riskier due to limited information (Stiglitz and Weisse,1981). Moral hazard occurs when the borrowers does not perform their duties according to the contract due to the separation between ownership and control. Due to the borrowers' active involvement in the business, the banks cannot directly ensure that the borrower is always acting in the banks' best interests. Due to its small size and low governance to control SMEs' operations, the extent of information asymmetry for SMEs becomes more serious as compared to large business.

According to Aggarwal and Yousef (2000), as information asymmetry problems become more severe, debt becomes the dominant financing instrument and this has restricts access to financing for certain segment of borrowers particularly SMEs.

Due to the information asymmetry problem as explained above, SMEs' financing usually expose the banks to higher risks profile and to mitigate their risks, the banks usually impose few conditions such as collateral and high interest rate. However, SMEs' lack of assets to be pledged as collateral (Berger and Udell, 1998). Furthermore, small business especially the new start up firms usually lack of financial track record and have difficulty in preparing the business plan as required by the bank (Berger and Udell; 1998, Aris; 2007 and Rasiah; 2011). In the absence of collateral, track record and business plans, SMEs are perceived as a high risk financing as their ability to repay the loan and growth of businesses are difficult to determine (Wattanapruttipaisan, 2003). Therefore, SMEs are usually charged with a relatively high interest rate as compared to the large business and this makes access to financing more difficult for SMEs (ShamsubaridahRamlee et al, 2013 and Berger \&Udell, 1998). High interest payment would definitely increase financial burden of SMEs. As SMEs operates in an uncertainty environment which does not guarantee the performance of the business, high interest commitment make them expose to financial distress, a situation where the borrowers have difficulties in paying off its debt to the lender (Pandey, 2005). 
Besides this, interest amount is calculated based on the interest rate which is fluctuating from time to time. As cited by Siti Khadijah (2010) in the Toutelian and Gaedeke, (1985), most of SME are undercapitalized and this makes them sensitive to the volatile interest rates.

The issues of collateral and high interest/ profit payment as practiced in debt financing system have also been criticized by many Muslim scholars. Chapra (1992) argued that collateral requirement results in an inequitable distribution of financing as financing will only be granted to those who have assets only. Hence, the poor and middle class entrepreneur may have difficulty in providing collateral as they have no assets to be pledged to the banks even though they have a talent and viable business. With this practice, chances of getting financing are not open to all entrepreneurs and concentrates to those who have assets. This obviously violates principle of justice which is the primary objective of Islam. Chapra's views are supported by Usmani (1998) who highlighted that due to the inability of SMEs to provide collateral, their access to external financing will be restricted and this would subsequently hinder the development of SMEs which is an important business segment to solve the major economic problems such as poverty and unemployment, especially in the Muslim countries.

Moreover, in the context of Islamic finance, there are consensus among Muslim jurists that interest element in debt is riba, which is strictly prohibited in Islam (Muhammad Ayub, 2007). Muslim jurists have put forwarded the economic rationales to explain why interest is prohibited in Islam. According to them, the practice of interest in the conventional financing is viewed as against the principle of justice which is the primary objective of Islam. To promote justice in the financial system, the risks associated with the financing shall be shared between the financiers and the borrowers (Chapra, 2007). In interest based financing, the risks and the entire burden of interest are shifted to the entrepreneur solely while the banks are guaranteed with a predetermined interest even in the event of losses (Chapra, 2007).

From the above, the way debt operates not only limit SMEs access to financing, but it also violates the principle of justice in Islam. Thus, an alternative financing which is not emphasize on collateral requirement and high interest need to be sought. Instead of relying on collateral and high interest payment, the alternative financing should consider the viability of the business and operates based on risks, profit and loss sharing. With these features, the alternative financing will enhance SMEs access to financing and at the same time uphold the principle of justice in Islam. Having said this, there is an Islamic equity financing namely Musharakah which operates differently from debt financing by using profit and loss sharing (PLS) principle. This study examines the viability of Musharakah as an alternative financing for SMEs. The following sections will discuss the three main features in Musharakah financing which is potentially to be applied in the SME financing.

\subsection{Potential of Musharakah Financing}

Musharakah is an Islamic equity based financing which operates based on the principle of profit and loss sharing between the partners. Musharakah operates based on few features which obviously differ from debt financing. The following subsections identify and discuss three variables in Musharakah financing that have direct relationship towards SMEs access for financing namely (i) participation (ii) risks sharing and (iii) profit and loss sharing.

\subsubsection{Bank's Participation}

In Musharakah financing, the banks become partners to the business and hold ownership in the firms. This provides them with direct access to the business information. With direct access to business information, all the partners now have same business information and therefore, information asymmetry problem as discussed in section 2.1 above will be mitigated. Furthermore, as a partner to the business, the banks have right to actively participate in business matters. Availability of timely information and right to participate in business matters will significantly assist banks in conducting effective monitoring and supervision on business operations (Ahmed, 2008; Al Jarhi, 2002 and Iqbal, 1997). This will mitigate the probability of moral hazard to happen. Besides that, the banks' participation in business operations will make them understand business conditions which will result in a continuous technical support and efficiency (Khan, 1997). From the above, banks' active participation in the business would mitigate problems arising from information asymmetry. Therefore, collateral requirement in debt financing to protect the banks from information asymmetry problems is not required and this will ease SMEs' access to financing. Thus, the participation element in Musharakah financing indicates potential of this type of financing to be a viable alternative financing for SMEs. 


\subsubsection{Risks Sharing}

Musharakah financing operates on the basic principle of risk sharing (Al ghurm bi al ghunm), meaning that the entitlement to return is associated with the risk taking. With this principle, all partners in Musharakah must assume risk associated with the financing in order for them to share the profit of the business. As the risks are shared among the partners, there is no need for SMEs to give a guarantee to the banks on the success of the business and therefore, collateral are not required. In this sense, banks would rely on the potential and viability of the business which is more suitable for SMEs that have viable business projects but lack tangible assets as collateral (Dusuki and Abozaid, 2007; Khan, 1997 and Al Harran, 1990).

Risks sharing also encourage entrepreneurship. According to Khan (1997), most of the entrepreneurs in developing countries are weak and do not have sufficient capacity to grow. Thus, when the risks are spread between the entrepreneur and the financier, this encourages more entrepreneurs to participate in the business activities. Risks sharing also encourage innovation (Al Harran, 1990). A study by Jalaluddin (1999) highlighted that risks sharing is well suited to small business as the banks will have an incentive to provide business support such as network and resources which can strengthen small businesses especially during economic downturn.

According to Mukhopadyay and Pendse (1983), risk sharing and incentive effect in profit sharing is greater in small businesses as these businesses are operated with a small capital and are financially less secured. Profit sharing is able to improve their attitude towards work and subsequently motivate entrepreneurs to work hard and generate more profit. This view is supported by Al Harran (1990) who found that risks sharing have an effect on morale and quality of work. This is due to a more positive perception and greater feeling of responsibility that increases the motivation of business partners. These advantages from risk sharing indicate that Musharakah has potential to function as a viable alternative financing for SMEs.

\subsubsection{Profit and Loss Sharing}

In Musharakah financing profit is distributed based on predetermined agreed ratio while losses are based on capital contribution ratio. Thus, the banks are not guaranteed with predetermined installment amount as return to the banks will be based on the actual outcome of the business. Since the actual outcome of the business will be shared, the banks will put more emphasize on the viability of the business to maximize their profit instead of ability to pay fixed interest amount which will provide SMEs with more access to financing. Moreover, Musharakah financing gives fair distribution to both borrowers and lenders during the profit and loss period (Usmani, 1998). Usmani has further emphasized that it is injustice to reward the bank only a small proportion of the profit leaving the rest to the borrowers in the event business generates big profit. It is also unjust on the part of the banks to claim a fixed rate of return without doing anything while the entrepreneur bears the entire loss in spite of his hard work and entrepreneurship (Chapra, 1998). In the context of Islamic finance, many Muslim scholars such as Chapra, Siddiqui, Usmani and Al Harran are of the opinion that Musharakah financing is the true spirit of Islamic financing as fair financing of Musharakah will bring justice to the contracted parties which is the primary objective of Islam. Based on the above, PLS in Musharakah financing that would enhance SMEs access to financing.

\section{Research Methodology}

Literature survey was conducted as presented in section 2 above and four variables with regards to the viability of Musharakah financing for SMEs have been identified namely (i) participation (ii) risks sharing (iii) profit and loss sharing trust and (iv) access to financing. In order to examine viability of Musharakah financing for SMEs, SMEs' views on these variables were collected. Data was collected by way of survey questionnaire. The questionnaires is divided into three parts which are part 1 (demographic information), part 2 (SMEs' awareness on Musharakah financing) and part 3 (SMEs' views on Musharakah financing). Part 3 involves 19 questions to measure SMEs' views on Musharakah financing. This study used Likert scale which requires the participants to indicate a degree of agreement or disagreement with each series of statement with regards to the respondents' views on Musharakah financing. A five point Likert Scale on 5 points were used to identify the responses to the questions on SMEs' views on Musharakah financing (Scale 1 - Strongly Disagree; 2- Disagree; 3- Neutral; 4- Agree and 5Strongly Agree). Sample of this study involves 100 SMEs in Klang Valley and Selangor, Malaysia. The questionnaires were distributed personally using drop-off method to each of the selected SMEs firms. Subsequently, exploratory factor analysis was performed to analyze SMEs views on each of variables in Musharakah financing to determine its viability as an alternative financing mode for SMEs. 


\section{Results}

Data obtained from the respondents were analyzed using exploratory factor analysis. This section discusses results of the data analysis and it is divided into three subsections i.e. (i) profile of respondents (ii) reliability analysis and (iii) factor analysis.

\subsection{Profile of Respondents}

Respondents for this study are 100 SMEs firms operate in Klang Valley and Selangor, Malaysia. Most of the respondents are the business owners who are also the operators of the business (44\%), which reflect the common way of SMEs operations where the owners are usually the operators of the business. The largest percentage of the business type is sole proprietorship with $60 \%$, follows by private limited companies of $29 \%$ and the remaining $11 \%$ is partnership firm. Most of the respondents (63\%) have annual sales less than RM300, 000 with less than 5 employees, which fall under micro status. This is consistent with the profile of SMEs in Malaysia which is dominated by micro firms. With regards to the business category, $52 \%$ of the respondents involve in manufacturing sector, $39 \%$ in services sector which is the two main sectors for SMEs in Malaysia. Thus, respondents' profiles are relevant and valid in representing and measuring SMEs' views on Musharakah financing. Summary of the respondents' profile are as shown in Table 1 below: -

Table 1: Demographic Information

\begin{tabular}{|c|c|c|}
\hline & Frequency & Percent \\
\hline \multicolumn{3}{|l|}{ Ownership } \\
\hline Business Owner & 26 & 26.0 \\
\hline Business Manager & 30 & 30.0 \\
\hline Business Owner - Operator & 44 & 44.0 \\
\hline \multicolumn{3}{|l|}{ Business Type } \\
\hline Sole Proprietorship & 60 & 60.0 \\
\hline Partnership & 11 & 11.0 \\
\hline Private Limited Company & 29 & 29.0 \\
\hline \multicolumn{3}{|l|}{ Business Category } \\
\hline Services & 39 & 39.0 \\
\hline Manufacturing & 52 & 52.0 \\
\hline Construction & 2 & 2.0 \\
\hline Agriculture & 2 & 2.0 \\
\hline Others & 5 & 5.0 \\
\hline \multicolumn{3}{|l|}{ Annual Sales } \\
\hline$<\mathrm{RM} 300,000$ & 63 & 63.0 \\
\hline RM300,001 - RM2,999,999 & 21 & 21.0 \\
\hline RM3,000,000 - RM14,999,999 & 8 & 8.0 \\
\hline RM15,000,000 - RM20,000,000 & 6 & 6.0 \\
\hline RM20,000,001 - RM50,000,000 & 2 & 2.0 \\
\hline \multicolumn{3}{|l|}{ Employee } \\
\hline$<5$ employees & 66 & 66.0 \\
\hline 5 - 29 employees & 20 & 20.0 \\
\hline $30-74$ employees & 14 & 14.0 \\
\hline
\end{tabular}

Source: self tailored 


\subsection{Reliability Analysis}

Reliability analysis was done using Cronbach's Alpha to confirm the reliability of all measurement items for each of the seven variables in Musharakah financing. Results of reliability analysis indicate that all measurement items are reliable as it achieved the minimum value of alpha 0.70 which concludes the variables are reliable measures. Details of the Cronbach's alpha values for all variables are as below: -

Table 2: Reliability Analysis

\begin{tabular}{|l|l|c|c|}
\hline No & Variables & $\begin{array}{c}\text { Reliability } \\
\text { (Cronbach's alpha) }\end{array}$ & No of Items \\
\hline 1 & Participation & 0.858 & 5 \\
2 & Risks Sharing & 0.830 & 5 \\
3 & Profit and Loss Sharing & 0.856 & 5 \\
4 & Access to financing & 0.874 & 4 \\
\hline
\end{tabular}

\subsection{Factor Analysis}

To examine viability of Musharakah financing for SMEs, SMEs views on 19 items with regards to the variables in Musharakah financing were gathered (as shown in Table 2). To analyze SMEs' views on the variables identified in the Musharakah financing, this study used Exploratory Factor Analysis due to the fact this technique can show which items belong together and which seem to indicate the same thing (Zainudin, 2012). This method assists the researcher to determine factors that contributes to the viability of Musharakah as a viable financing mode for SMEs. In order to run factor analysis, the sampling size must be adequate. Result of Kaiser-Meyer-Olking (KMO) in this study measure the sampling adequacy score of 0.800 which is above the recommended 0.5 levels (Field, 2005), indicating the sample size is adequate to perform factor analysis. The Bartlett's Test of Sphericity reached statistical significant $(\mathrm{p}=0.0000)$. Thus, factor analysis is considered an appropriate technique for analyzing the data.

Table 3: KMO and Bartlett's Test

\begin{tabular}{|c|c|c|}
\hline KMO and Bartlett's Test & \multicolumn{2}{|c|}{} \\
\hline $\begin{array}{c}\text { Kaiser-Meyer-Olkin } \\
\text { Adequacy. }\end{array}$ & Measure of Sampling & 1444.267 \\
\hline Bartlett's & Approx. Chi-Square & 171 \\
Test of & Df & .000 \\
Sphericity & Sig. & \\
\hline
\end{tabular}

The principal component analysis was performed to identify the numbers of underlying factors. All 19 items were analyzed simultaneously and they are grouped into four factors (as shown in Table 4 below), consistent with four numbers of independent and dependent variables identified earlier in section 3. From the total variances explained in Table 4, the top four components in the table show the initial eigenvalues as more than 1 and form a strong argument for representing the factors. Moreover, the cumulative percentage of variance for the top four components was $71.62 \%$, which indicated that these variances can be explained in Musharakah financing for SMEs. In other words, it means that more than $71.62 \%$ of the variances in Musharakah financing can be explained by these four generated components

Table 4:Total Variance Explained

\begin{tabular}{c|c|c|c|c|c|c|}
\hline \multirow{2}{*}{ Component } & \multicolumn{2}{|c|}{ Initial Eigenvalues } & \multicolumn{4}{|c|}{ Extraction Sums of Squared Loadings } \\
\cline { 2 - 7 } & Total & $\%$ of Variance & Cumulative \% & Total & $\%$ of Variance & Cumulative \% \\
\hline 1 & 7.481 & 39.375 & 39.375 & 7.481 & 39.375 & 39.375 \\
2 & 3.502 & 18.432 & 57.807 & 3.502 & 18.432 & 57.807 \\
3 & 1.590 & 8.368 & 66.176 & 1.590 & 8.368 & 66.176 \\
4 & 1.035 & 5.448 & 71.624 & 1.035 & 5.448 & 71.624 \\
\hline
\end{tabular}


Nevertheless, with reference to the scree plot in Table 5 below, there is quite a clear break between the third and fourth components. Therefore, it was decided to retain only three components in the analysis.

\section{Table 5: Scree Plot}

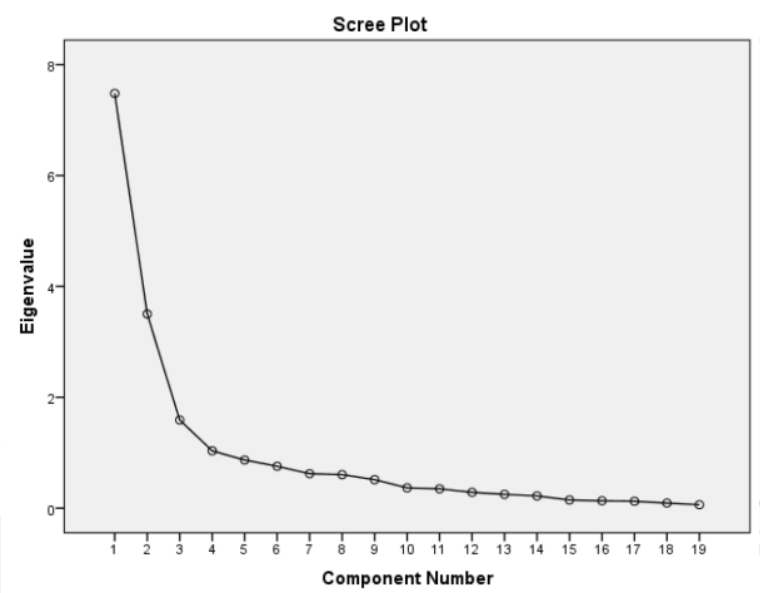

To aid the interpretation of the three components, varimax rotation was performed and the results are as shown below in Table 6 - Total Variance Explained (based on three components) and Table 7 - Rotated Component Matrix. With reference to Table 7 (Rotated Component Matrix) the two variables identified earlier namely (i) risks sharing and (ii) PLS have been grouped into one factor only i.e. factor 1 (risks, profit \& loss sharing). Another two factors are consistent with the earlier variables identified in section 3 i.e. factor 2 (access to financing) and factor 3 (banks' participation). Three statements are deleted as the factor loading is below 0.55 leaving only 16 statements.

Table 6 : Total Variance Explained (based on three factors only)

\begin{tabular}{|c|c|c|c|c|c|c|c|c|c|}
\hline \multirow{2}{*}{$\begin{array}{c}\text { Compo- } \\
\text { nent }\end{array}$} & \multicolumn{3}{|c|}{ Initial Eigenvalues } & \multicolumn{3}{c|}{$\begin{array}{c}\text { Extraction Sums of } \\
\text { Squared Loadings }\end{array}$} & \multicolumn{3}{c|}{$\begin{array}{c}\text { Rotation Sums of } \\
\text { Squared Loadings }\end{array}$} \\
\cline { 2 - 9 } & Total & $\begin{array}{c}\% \text { of } \\
\text { Variance }\end{array}$ & $\begin{array}{c}\text { Cumulative } \\
\%\end{array}$ & Total & $\begin{array}{c}\text { \% of } \\
\text { Variance }\end{array}$ & $\begin{array}{c}\text { Cumulative } \\
\%\end{array}$ & Total & $\begin{array}{c}\% \text { of } \\
\text { Variance }\end{array}$ & $\begin{array}{c}\text { Cumulative } \\
\%\end{array}$ \\
\hline 1 & 7.481 & 39.375 & 39.375 & 7.481 & 39.375 & 39.375 & 4.993 & 26.279 & 26.279 \\
2 & 3.502 & 18.432 & 57.807 & 3.502 & 18.432 & 57.807 & 3.796 & 19.981 & 46.261 \\
3 & 1.590 & 8.368 & 66.176 & 1.590 & 8.368 & 66.176 & 3.784 & 19.915 & 66.176 \\
\hline
\end{tabular}

With reference to Table 6 (Total Variance Explained), factor 1 (risks, profit and loss sharing) has the highest Eigen value (7.481) and variance (39.375), it automatically signifies as the most important factor perceived by SMEs in Musharakah financing. This is followed by factor 2 (access to financing) (Eigen value $=3.502$, variance $=18.432 \%$ ) and factor 3 (bank's participation) $($ Eigen value $=1.590$, variance $=8.368 \%$ ). 
Abdul Razak et al

Table 7 : Rotated Component Matrix

\begin{tabular}{|c|c|c|c|c|}
\hline & Statements & $\begin{array}{c}\text { Factor } 1 \\
\text { Risk, profit \& } \\
\text { loss sharing }\end{array}$ & $\begin{array}{c}\text { Factor } 2 \\
\text { Access } \\
\text { to } \\
\text { financing }\end{array}$ & $\begin{array}{c}\text { Factor } 3 \\
\text { Participa } \\
\text { tion }\end{array}$ \\
\hline (1) & $\begin{array}{l}\text { Bank as business partners would care more about the } \\
\text { business }\end{array}$ & \multirow{9}{*}{$\begin{array}{l}.822 \\
.791 \\
.770 \\
.681 \\
.663 \\
.655\end{array}$} & & \\
\hline (2) & Risks sharing encourages SMEs' innovation. & & & \\
\hline (3) & Motivates business expansion & & & \\
\hline (4) & Both parties will be committed to business success & & & \\
\hline$(5)$ & Can reduce bankruptcy risk for SMEs. & & & \\
\hline (6) & Banks need to share associated risks with SMEs & & & \\
\hline (7) & $\begin{array}{l}\text { Musharakah financing is based on the viability of the } \\
\text { business }\end{array}$ & & & \\
\hline (8) & $\begin{array}{l}\text { Fair distribution of profit and loss to both banks and } \\
\text { SMEs. }\end{array}$ & & & \\
\hline (9) & $\begin{array}{l}\text { Not put heavy burden on SME at times of slow- down in } \\
\text { business }\end{array}$ & & & \\
\hline (10) & $\begin{array}{l}\text { Musharakah financing promotes SMEs' growth and } \\
\text { expansion }\end{array}$ & & \multirow{3}{*}{$\begin{array}{l}.843 \\
.840 \\
.839\end{array}$} & \\
\hline (11) & Musharakah financing enhance SMEs access to financing & & & \\
\hline (12) & Musharakah financing suit with new start-up business & & & \\
\hline (13) & Bank's participation result in more effective monitoring. & & & \multirow{4}{*}{$\begin{array}{l}.926 \\
.916 \\
.903 \\
.816\end{array}$} \\
\hline & $\begin{array}{l}\text { Bank's participation makes them understand business's } \\
\text { condition. }\end{array}$ & & & \\
\hline (15) & $\begin{array}{l}\text { Bank's participation result in continuous technical } \\
\text { support. }\end{array}$ & & & \\
\hline (16) & Banks need to participate in SME's business operations. & & & \\
\hline
\end{tabular}

Table 7 presents the three factors along with scores for each items grouped under each factor. Factor 1 which is risks, profit and loss sharing is measured by 9 items, factor 2 (access to financing) measured by 3 items and factor 3 (participation) measured by 4 items.

\section{Discussion}

The initial results of factor analysis has regarded that there were four variables deemed to be relevant in Musharakah financing for SMEs which are (i) risks sharing (ii) participation (iii) access to financing and (iv) PLS. However, results from factor analysis show most of the measurements items in risks sharing and PLS were grouped together in one single factor. Therefore, as supported by scree plot, these four variables were then grouped into three factors/ variables only namely (i) risk, profit and loss sharing (ii) access to financing and (iii) participation. Thus, this study indicates that these variables which were identified earlier in the literature surveys are valid to measure viability of Musharakah financing as an alternative financing for SMEs. Out of these three variables, risks, profit and loss sharing is the most important factor perceived by SMEs in Musharakah financing. It should be noted that this factor is also the main differences between Musharakah and debt financing. SMEs high interest on this factor indicates they are interested with Musharakah financing as risks, profit and loss sharing factor is believed would remedy problems faced by them in debt financing system that put burden of business risks and predetermined installment solely on SMEs. Therefore, findings

(c) COMSATS Institute of Information Technology Lahore, Pakistan. 
supported relevance of Musharakah financing for SMEs as suggested by this study. Another factor which is banks' participation in SMEs business operations is also perceived as an important factor for SMEs in Musharakah financing. For Musharakah to be a viable financing, SMEs' perceive that active participation of the banks' in the SMEs' business operations is necessary. Furthermore, it is also found that

Musharakah can enhance SMEs' access to financing. This would provide SMEs with sufficient fund to facilitate their growth and development. Therefore, findings from this study have empirically supported previous literatures with regards to the validity of variables in Musharakah financing for SMEs. With these findings, it can be concluded that Musharakah has potential to be a viable alternative financing for SMEs.

This study contributes differently from past studies in the same area by Veelaiporn et al (2013) and MohaAsri and Siti Khadijah (2012). Siti Khadijah (2012) explored potential of PLS financing for SMEs and found PLS is perceived to have lots of business and economic advantages to the SMEs. Study on the viability of PLS financing for SMEs in Malaysia was also done by Veelaiporn, Shamsher and Taufiq (2013). In their study, viability of PLS is determined by calculating the impact of PLS to SMEs' profitability and it was found that PLS benefits SMEs with their stable profit position. Different from these two studies, viability of Musharakah financing in this study is determined by examining validity of each variables in Musharakah identified earlier from the past literatures. Thus, this study provides solid foundation and direction in structuring Musharakah as an alternative financing mode for SMEs.

\section{Conclusion}

The main objective of this study is to examine the viability of Musharakah financing as an alternative financing mode for SMEs. Findings from this study which is obtained from the demand side ascertained and confirmed features of Musharakah financing have a potential as a viable alternative financing mode for SMEs. The results have managerial implications for the banks. As the findings imply, the Islamic banks need to consider the viability of Musharakah financing to provide SMEs' with greater access to financing which in turn, would facilitate SMEs to further grow and expand. Elements of banks' participation, risks, profit and loss sharing in Musharakah financing as discussed in this study not only facilitate SMEs to get more access to financing, but it is closer to the objectives of Islam which is to establish justice as compared to the current debt financing system. This provides new direction to both banks and SMEs in promoting SMEs industry which is the backbone of the economics of the country. Nevertheless, Musharakah financing is a new dimension of financing that have many challenges to implement that. Thus, in order to implement Musharakah financing, those challenges, particularly participation, risks, profit and loss sharing need to be addressed seriously by the banks. In relation to this, the banks in Malaysia may need to refer to the practice of Musharakah financing in other countries previously such as Sudan, Iran and Indonesia. The study has also contributed to the existing knowledge related to Islamic banking theory and practice. Further studies in this area need to done so that both SMEs and Islamic banks can grow side by side which at the end benefit the overall economic condition.

\section{References}

Aggarwal, R. K., \& Yousef, T. (2000). Islamic banks and investment financing. Journal of money, credit and banking, 93-120. Ahmed, G. A. (2008). The implication of using profit and loss sharing modes of finance in the banking system, with a particular reference to equity participation (partnership) method in Sudan. Humanomics, 24(3), 182-206.

Akerlof, G. A. (1970). The market for" lemons": Quality uncertainty and the market mechanism. The quarterly journal of economics, 488-500.

Al-Harran, Saad A. S. (1993). Islamic Finance: Partnership Financing.Pelanduk Publications (M), Petaling Jaya

Al-Harran, Saad A. S. (1990). Islamic finance: the experience of the Sudanese Islamic Bank in partnership (musharakah) financing as a tool for rural development among small farmers in Sudan (Doctoral dissertation, University of Durham).

Al-Jarhi, M. A. (2002). Islamic Finance: An Efficient and Equitable Option. Islamic research and training institute, Islamic development Bank.

Beck, T., \&Demirguc-Kunt, A. (2006). Small and medium-size enterprises: Access to finance as a growth constraint. Journal of Banking \& Finance, 30(11), 2931-2943.

Berger \& F Udell, G. (1998). The economics of small business finance: The roles of private equity and debt markets in the financial growth cycle. Journal of Banking \& Finance, 22(6), 613-673.

Chapra, M. Umer (2007). Challenges facing the Islamic financial industry. Handbook of Islamic Banking, 325.

Chapra, M. Umer (1992). Islam and the Economic Challenge. United Kingdom: The Islamic Foundation and The International Institute of Islamic Thought.

Dusuki, A. W., \&Abozaid, A. (2007). A Critical Appraisal On The Challenges Of Realizing Maqasid Al-Shariaah In Islamic Banking And Finance. International Journal of Economics, Management and Accounting, 15(2). 


\section{Abdul Razak et al}

Funding in Malaysia. Unpublished doctoral dissertation. Durham University

HasnahHaron, Saniza Said, Jayaraman\&Ishak Ismail (2013). Factors Influencing Small Medium Enterprises (SMES) in Obtaining Loan. International Journal of Business and Social Science Vol. 4 No. 15 [Special Issue - November 2013]

HlupekoDube (2013). The Impact of Debt Financing on Productivity of Small and Medium Scale Enterprises (SMEs) : A Case Study of SMEs in Masvingo Urban. International Journal of Economics, Business and Finance Vol. 1, No. 10, November 2013, PP: 371-381, ISSN: 2327-8188 (Online).

Iqbal, Z. (1997). Islamic financial systems. Finance and Development, 34, 42-45.

Jalaluddin, A. (1999). Attitudes of Australian small business firms and financial institutions towards the profit/loss sharing method of finance. Unpublished doctoral dissertation. Durham University.

Khan, T. (1997). An analysis of risk sharing in Islamic finance with special reference to Pakistan. Unpublished doctoral dissertation. Loughborough University.

MohaAsri\&Siti Khadijah (2012). Perception of Small-and Medium-Sized Enterprises in Klang Valley, Malaysia towards Profit and Loss Sharing Mode of Financing. Malaysian Journal of Economic Studies, 49(1).

MohaAsri and Siti Khadijah (2011). Small and Medium Enterprises and Their Financing Patterns: Evidence from Malaysia. Journal of Economic Cooperation and Development, 32(2), 1-18.

Muhammad Ayub (2007). Understanding Islamic Finance (Vol. 462). John Wiley \& Sons.

Mukhopadhyay, A. K., \&Pendse, S. (1984). Profit Sharing in Small Business : An Analysis of Risk and Incentive Effects. Journal of Small Business-Canada, 1(3),9-14.

NormahAris, N. M. (2007). SMEs: Building Blocks for Economic Growth.

Oum, S., Harvie, C., \&Narjoko, D. (2011). Small and medium enterprises' (SMEs') access to finance in selected East Asian economies.

Rasiah, R. (2011). Financing small and medium manufacturing firms in Malaysia. Small and Medium enterprises (SMEs) access to finance in selected East Asian economies, 231-260.

Saleh, A. S., \&Ndubisi, N. O. (2006). An evaluation of SME development in Malaysia. International Review of Business Research Papers, 2(1), 1-14

ShamsubaridahRamlee\&BermaBerma (2013). Financing gap in Malaysian small-medium enterprises: A supply-side perspective. South African Journal of Economic and Management Sciences, 16(5), (2013). 115-126.

Shinozaki, S. (2012). A New Regime of SME Finance in Emerging Asia: Empowering Growth-Oriented SMEs to Build Resilient National Economies. Asian Development Bank.

Siddiqi, M. N. (2006). Islamic banking and finance in theory and practice: A Survey of state of the Art. Islamic economic studies, $13(2), 1-48$

Siddiqi, M. N. (1981). Rationale of Islamic banking. International Centre for Research in Islamic Economics King AbdulazizUniversity.

Stiglitz, J. E., \& Weiss, A. (1981). Credit rationing in markets with imperfect information. The American economic review, 393-410.

Taqī‘Usmān̄̄, M. (1998). An introduction to Islamic finance. ArhamShamsi.

VeelaipornPromwichit, ShamsherMohamad and Taufiq Hassan (2013). The Viability of Profit and Loss Sharing Based Financing for Malaysian SMEs. International Business Management, 7: 278-287.

Wattanapruttipaisan, T. (2003). Four proposals for improved financing of SME development in ASEAN. Asian Development Review, 20(2), 66-104.

Zainudin Awang (2012), Research Methodology and data Anaysis.2nd ed. UiTM Press. 